\title{
LOVED GARMENTS: OBSERVED REASONS FOR CONSUMERS USING AND HOLDING ONTO GARMENTS
}

\author{
Rebekah Harman
}

\section{INTRODUCTION}

A key disruptor within the fashion industry globally is the drive towards a more ethical and sustainable fashion industry. According to respondents from The State of Fashion's 2020 survey, sustainability is seen as being "both the single biggest challenge and the single biggest opportunity" (Amed et al., 2020, p. I6) for the fashion industry. Waste from the fashion industry is high. In Aotearoa New Zealand over 190,000 tonnes of textiles yearly go to landfill (based on 2019 figures), adding to carbon emissions (Casey, 202I). Clearly, further work must be done immediately to reduce the amount of waste. While some fashion companies are making progress towards reducing waste in manufacturing and production, the role of the consumer is an important one. Although the Pulse of the Fashion Industry report discusses how consumers are becoming more aware of sustainability, these concerns are not yet powerful enough to be the strongest driver when purchasing (Lehmann et al., 2019, p. 2). According to a 2015 study in Britain by Barnardo's, on average each item of clothing purchased is worn seven times before it is thrown away (Thomas, 2019). Research by the Massachusetts Institute of Technology estimates that 150 billion garments are produced every year globally (Koperniak, 20I5). Data from the United Nations indicates that by 2030 the world population is expected to reach 8.5 billion (United Nations, 20 I5), a growth rate of between 0.9 and I percent, while during this same period apparel consumption is expected to rise by 63 percent (Eder-Hansen et al., 2017, p. 8).

This article reports on research designed to learn more about the drivers that contribute to people holding onto garments and wearing them continuously over a long period of time. The research was based in the Waikato region of Aotearoa New Zealand and uses in-depth interviews, a qualitative method to "explore and gain a deep understanding of phenomena" (Chrysochou, 2017, p. 4I3), framed as case studies. In-depth interviews allow the researcher to gain deeper knowledge and insights than methods such as focus groups and other forms of qualitative research appropriate for investigating consumer behaviour would allow (Chrysochou, 2017). For the research project, in March 2019 five people across a range of genders, ethnicities and ages were invited to participate in semistructured interviews. The seven stages suggested by Kvale (1996) were used for conducting the in-depth interviews. Extensive notes were made during the interviews, which were recorded for transcribing later. The interviews were later analysed for common words and themes. The following question was the key research question:

What makes people retain clothing items, and continue to wear them over several years?

In what follows, I first give an overview of the literature dealing with consumer behaviour and product attachment, along with consumerism and slow fashion. A summary of findings from each of the five case studies follows. Then there is a discussion (including a demonstration of the key findings in Figure $\mathrm{I}$ I), followed by a conclusion. 


\section{CONSUMER BEHAVIOUR AND PRODUCT ATTACHMENT}

Consumer behaviour theory studies how consumers make decisions about goods or services, either at the purchase, use or disposal stage. This paper is concerned with the use stage of consumer behaviour, rather than the purchasing or disposal phases. According to Tim Cooper, professor of sustainable design and consumption at Nottingham Trent University: "Academic study of consumer behaviour, which emerged in a marketing context, has focussed on the purchase phase in the product life cycle, but understanding the subsequent phases of use and disposal is increasingly vital" (Cooper, 2005, p. 64). Cooper's statement emphases the need for further research regarding the use and disposal of products.

There are three major types of theory used to explain consumer behaviour - economic theory, psychological theory and anthropological theory. Understanding consumer behaviour from a purely economic perspective is not helpful when examining consumers who are changing to sustainable clothing options (Zhang et al., 2021, p. 5). Kate Fletcher argues that sustainability in the fashion industry should be based on the way people use clothes and consumers' real experiences (Fletcher, $20 \mathrm{II}$ ). Fletcher's ideas fit within the psychological theory of consumer behaviour, which deals with consumers' personal experiences.

Product attachment refers to the emotional bond that can be formed between a person and an object (Scheifferstein et al., 2004). People may become attached to a product for a variety of reasons, including the sense that a particular product matches a person's self-identity, or positive memories that come to be associated with a product (Ko et al., 20I5). It is widely accepted that the way that individuals clothe their bodies is an active process, with decisionmaking going into what clothing to wear. Thus, clothing can be the outer expression of a person's self-identity. Additionally, ordinary living offers many opportunities to associate positive memories with a particular item of clothing. And because sustainability is a value, it has its own emotions attached to it. Research by Ko et al. proposes that "product attachment results whenever there is a strong commitment and emotion towards a product" (20I5, p. 175). When looking to understand what makes people hold onto garments and wear them for a long period of time, it is important to understand individuals' attachment to a particular garment, including the role of positive memories and self-identity, and concerns about the sustainability of the fashion industry.

\section{CONSUMERISM AND SLOW FASHION}

Consumerism encourages the acquisition of goods and services, often with little consideration of what goods and services might be needed, rather than wanted. In Vance Packard's book on consumerism, The Waste Makers ( 1960), he makes the correlation between the rise of consumerism in America and wasteful behaviour. Packard equates the term consumerism with waste, creating a negative image (Packard, 1960). Whereas Packard's book gives a generalised overview of consumerism, Naomi Klein's book No Logo:Taking Aim at the Brand Bullies, published in 1999 , gives fashion-related examples when examining the negative activities of brands such as Nike, along with strategies for the buying public to fight the waste generated by consumerism (Klein, 1999).

The rise of the term sustainability and sustainability as an issue in the late twenty-first century has been neatly summarised as "activities that can be continued indefinitely without causing harm to the environment, the way that you expect to be treated and you treat others, and the consideration that meets a current generation's needs without compromising those of future generations" (Zhang et al., 202I, p. 4).

Current trends for slow fashion encourage consumers to slow down their fashion consumption, taking time to consider what to purchase and how many wears they will get out of a garment, as a strategy to lower the amount of fashion waste. The slow fashion trend is in reaction to the amount of waste in the fashion industry, in addition to historical events such as Rana Plaza. 
The Rana Plaza disaster of 2013 was a devastating event where I I 34 garment factory workers were killed in 90 seconds following the collapse of a building in Dhaka, Bangladesh (Safi et al., 20 I 8). This disaster led to movements such as Fashion Revolution, a fashion activism movement that has been running since 20 I3. Fashion Revolution has a number of aims including bringing an "end to throwaway culture and a shift to a system where materials are used for much longer and nothing goes to waste" (Fashion Revolution, n.d., para. 5). Fashion Revolution oversees a worldwide activism week every year in April, drawing attention to the lack of sustainability and ethical practices within the fashion industry. This research project was prompted by one of the activisms suggested by Fashion Revolution Week - writing a love story about your favourite item of clothing as a way to promote slower consumption (Fashion Revolution, 2017).

While there is a recognised need to further understand how individuals use and dispose of clothing items, there is limited in-depth research on these activities. As more research is done into design and emotion, there is potential for fashion designers to understand strategies for designing clothing that will enable or encourage consumers to hold onto their clothing and wear it over a longer period of time.

\section{FINDINGS}

In this section, findings from each of the five interviews are presented. The participants interviewed all had an interest in the topic, but no specialist knowledge of or training in the fashion industry. They all described one or two garments that they loved and had worn over a number of years.

\section{Interview I:Xavier}

The item that Xavier chose to talk about was a zarape (sometimes spelt serape or sarape) - a long, blanket-like shawl with a cut-out for the head to fit through. Xavier now lives in Aotearoa New Zealand, but grew up in México and purchased the zarape in the mid-1970s (see Figures I \& 2).

For Xavier, the zarape evoked a particular memory. He was reminded of traveling high up in the mountains through México with his partner and his brothers - they were wearing their zarapes and they took a group photo. Xavier was reminded of the spot they travelled to and being with the important people in his life. Growing up in México, this memory was very important to Xavier - in addition to owning a zarape, which he described as a part of every Méxican's story.

It was important to Xavier that the garment was multifunctional and simple - an item that he reached for again and again. He described how it can be used as a rug for a picnic, a blanket for sleeping at a friend's house or something to take with you when traveling. He had chosen this item to talk about as he had been able to get so much use out of it in many different contexts. The aesthetics of the garment also appealed to Xavier, and he used strong, positive, emotive language to describe it: "I have some other ones that have beautiful patterns and are complex, but this one is such a

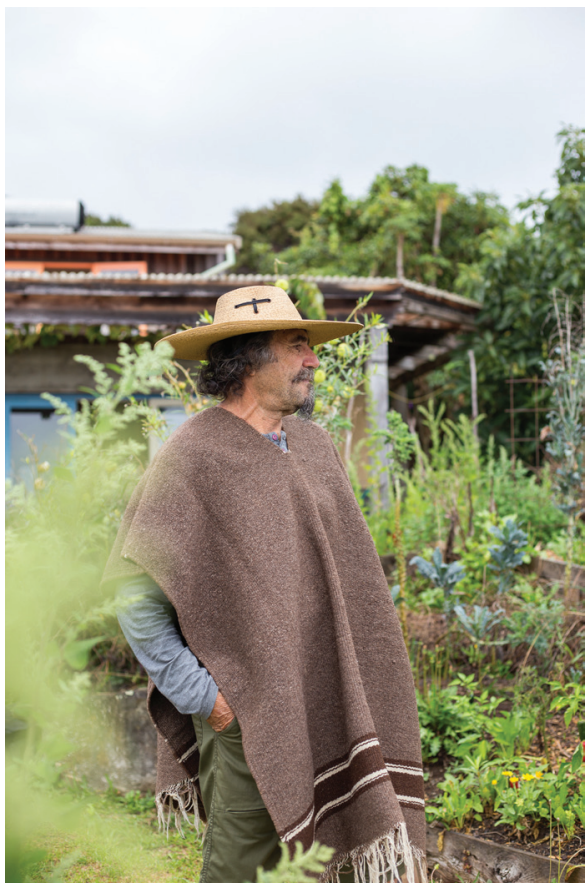

Figure I. Xavier Meade wearing his zarape, which he describes as "neutral, elegant and easy to wear." Photograph: Holly Russell, 2019. 
neutral, elegant, easy-to-wear - I really love it and I take it everywhere." "If I travel, I still take it with me, and it is an extra blanket that I take with me; if we stop for a picnic, I still use it. I always find a use" (Xavier Meade in conversation with Rebekah Harman. Interview, April I, 2019).

The zarape was made of a heavy, coarse wool. Xavier mentioned liking the fact that it still smells of lamb and that he has had to remove pieces of grass for years after first acquiring it. For him, this was a connection with nature and natural fibres something he finds important when he thinks about ethical clothing.

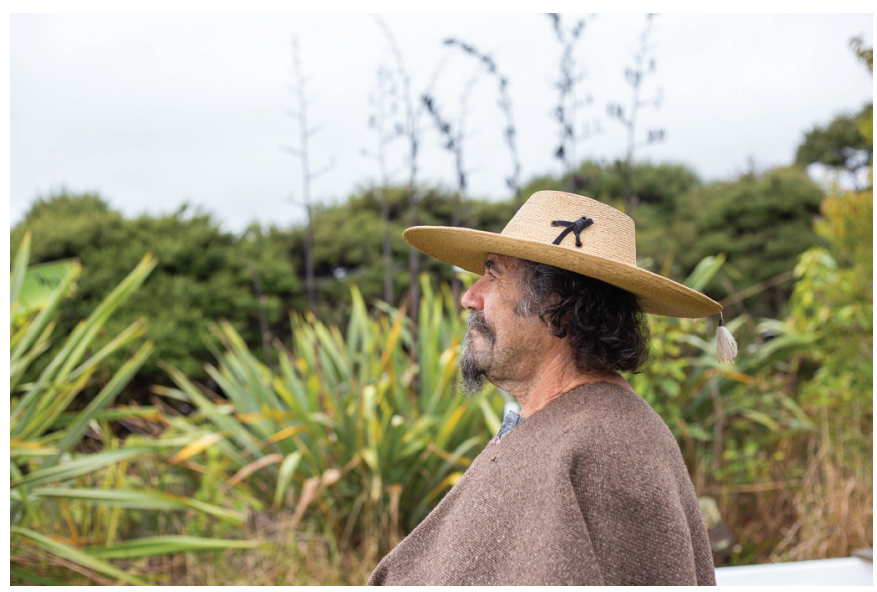

Figure 2. Xavier Meade wearing his zarape. Photograph: Holly Russell, 2019.

\section{Interview 2: Leafa}

The item that Leafa chose to talk about was a brightly coloured wool poncho, covered in a tartan pattern. Leafa spoke of purchasing it 12 years ago from SaveMart, a recycled clothing store with branches around Aotearoa New Zealand. The poncho is labelled as Made in New Zealand by Parisien Knitters. It was likely to have been manufactured in the early 1970s (see Figures 3 \& 4).

Leafa was initially attracted to the garment because of its aesthetics and the warmth of the natural wool fibres it was made from. Asserting that she loved the poncho's "loud, bright clashing colours," she described feeling like it was a blanket when wearing it.

Leafa had strong childhood memories of wearing a very similar garment: "It reminds me too of when I was a little kid. I had one the exact same colours - slightly different pattern - when I was five or six. I remember wearing it to Strathmore School." These memories and sense of place appeared to enhance her sense of attachment to the garment.

Leafa also spoke about she enjoyed purchasing second-hand clothing, and how these feelings came from positive memories of second-hand shopping with

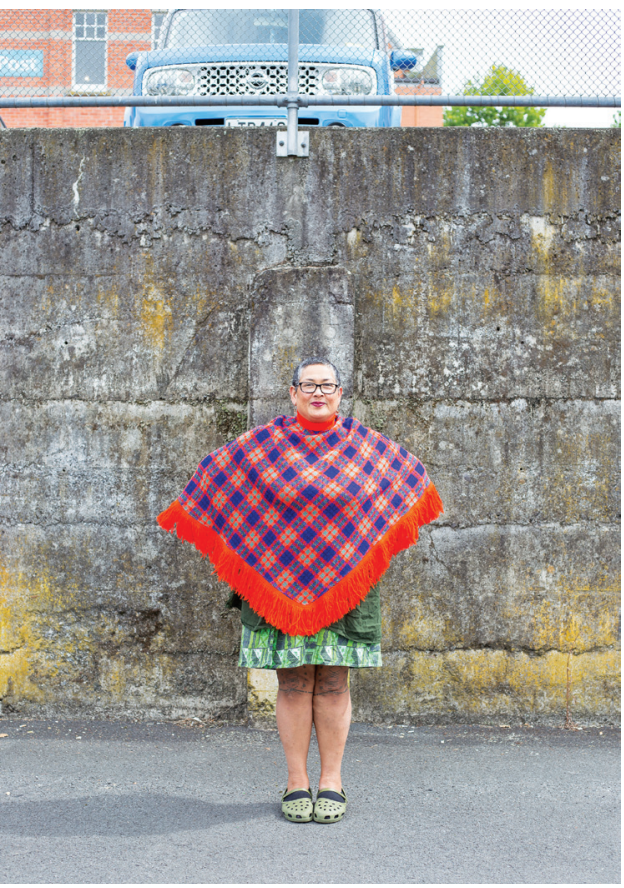

Figure 3. Leafa Wilson wearing her poncho; she was drawn to this garment due to its "loud, bright, clashing colours."

Photograph: Holly Russell, 2019. family when she was a child. Additionally, she enjoyed the sense of adventure and discovery that came with this process. Sustainability within the fashion industry is a concern for Leafa; she spoke of being aware of the benefits to the environment of purchasing second-hand clothing. 


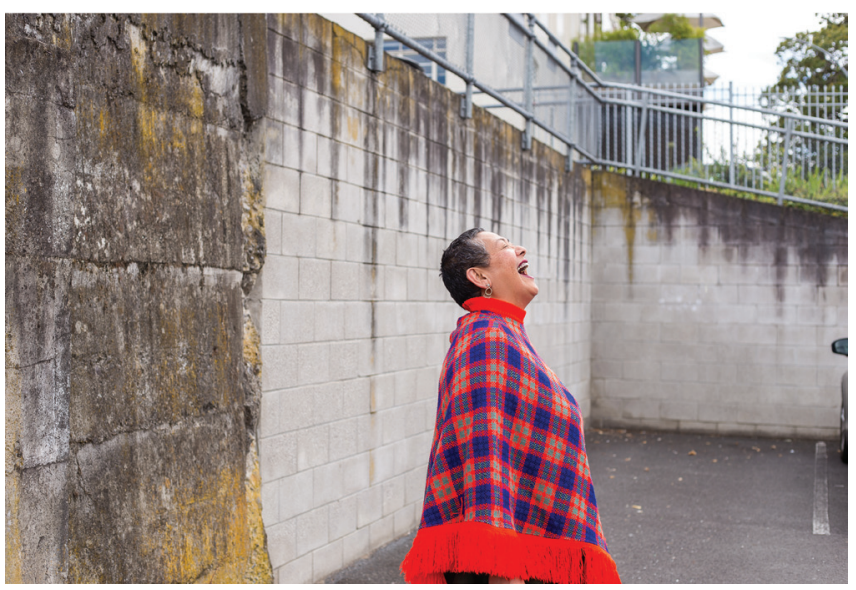

Figure 4. Leafa Wilson wearing her poncho. Photograph: Holly Russell, 2019.
Overall, the durability of this thick wool garment came through as important to Leafa. She also expressed strong emotions about the garment: "This is one thing that I will continuously wear throughout the rest of my days. Because it is so hardwearing, I can trust that it is not going to let me down in the freezing cold weather. I feel great when I wear my poncho! It makes me feel positive and makes others feel positive too" (Leafa Wilson in conversation with Rebekah Harman. Interview, March 4, 2019).

\section{Interview 3: Lauren}

The item that Lauren chose to talk about was a square scarf, with a rich black, red, green and white floral pattern laid over it (see Figures 5 \& 6).

Lauren spoke of purchasing the scarf ten or II years ago at the Camden Market in London. The scarf seemed to symbolise a defining point in her life, as Lauren spoke of desperately wanting to visit Camden Market for a long time and being very interested in vintage shopping. She had strong memories of purchasing the scarf and it being a positive experience. The scarf was the first thing she found and purchased at the Camden Market that day.

Lauren spoke of the scarf having many different "re-incarnations" and being very versatile - she has worn it around her neck, as a headscarf and used it in photoshoots, attached to her bags and around her ankle. Lauren said that every season she would find new ways to wear the scarf and continues to wear it two to three times a week. She feels excited when she wears it: "It's irreplaceable now, it's completely irreplaceable. I don't think l'd be able to find another scarf like it, because of its specific patterning and colouring. It reminds me of places and times and certain fashion moments that l've gone through in the past as well. It holds a lot of memories, that's for sure ... it's been around the world with me" (Lauren Mann in conversation with Rebekah Harman. Interview, March 18,2019).

Lauren is thoughtful when purchasing new items, considering the types of fabrics she purchases and the production values that go into making clothing.

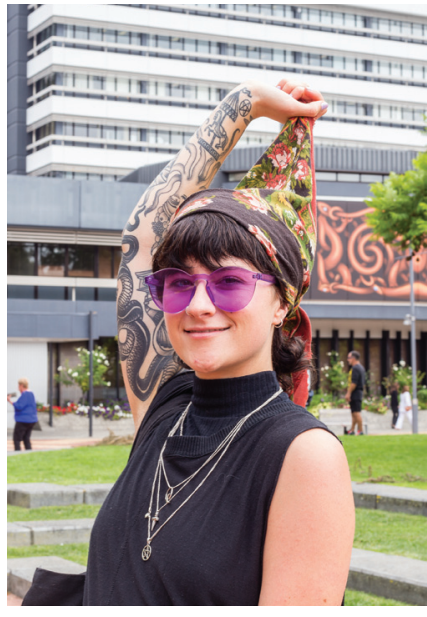

Figure 5. Lauren Mann wearing the scarf that reminds her of "places, times and certain fashion moments."

Photograph: Holly Russell, 2019.

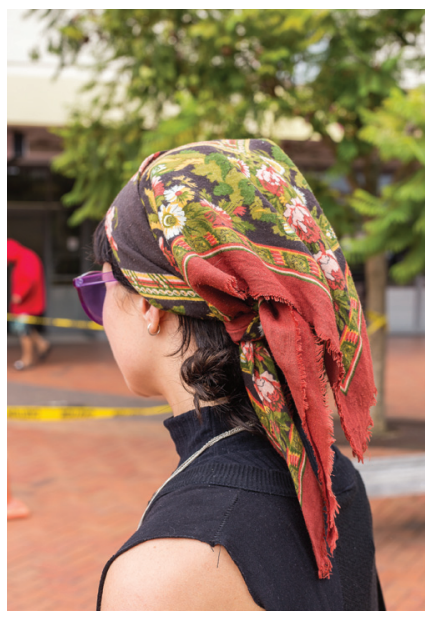

Figure 6. Lauren Mann wearing her scarf. Photograph: Holly Russell, 2019. 


\section{Interview 4:Tim}

The items that Tim chose to talk about were a leather satchel with minimal stitch detailing, in a soft tan colour, and a leather jacket in a dark brown leather with exposed zips. Both items have been well worn over the time that Tim has owned them, and both were purchased on a family trip to Pondicherry, India, in 2006 (see Figures 7 \& 8).

Tim spoke of how the jacket and the satchel were sentimental reminders of the family trip and how the items make him feel good when he wears them. According to Tim, "it really started this love affair we had with India," to the point where one of his sons returned to India and lived there for three years following the family trip. His son then went on to start a business called The Loyal Workshop, a key objective of which was to give women opportunities to leave working conditions that amounted to slavery. The business makes leather bags and was inspired by the bag that Tim purchased.

Tim spoke of the patina that had formed on the leather over time and how this was a beautiful aesthetic feature of leather. From a practical perspective, Tim liked the warmth, sense of security and protection the jacket offered, especially as he regularly wears it when motorcycling. When purchasing garments, he considers the materials used and where something is made. Referring to the aesthetics of these leather items, he categorises them as an Americanised masculinity - something he likes. He spoke of using the bag as his work bag every day since he purchased it in 2006, and using the jacket regularly for motorcycling (Tim Croucher in conversation with Rebekah Harman. Interview, March 18, 2019).

\section{Interview 5: Carolyna}

The item that Carolyna chose to talk about was a huipil, worn with a rebozo. The huipil is a tunic-like garment that is traditionally worn by women in México and Central America. The huipil worn by Carolyna is of white cotton, with colourful fringing and embroidery down the centre front. The rebozo is a rectangular, woven piece of cloth that is also traditionally worn by women from México; it can be worn in a variety of ways. Carolyna's rebozo is woven, with a dark red, black and white pattern (see Figures 9 \& 10).

Carolyna lived in México for five years and her partner is Méxican. The huipil was a gift from her partner's brother in the early 1990s and holds very special value and memories for Carolyna. "I lived in México for five years - those times are who I am now. Those times were so formative for me now, for a lot of things. It kind of answered for me why I left New Zealand - at that time I had to leave, I didn't know why, I couldn't breathe, I couldn't see my life 
in the 60s taking something that was going to be so predictable, I didn't have enough information on how to live." She enjoys the simplicity of the garments and finds a sense of tranquillity in wearing them.

For Carolyna, ethical fashion means natural fibres, organically grown in biodiversity, moving away from monocultural practices. When she wears the huipil with the rebozo, she says, "I can feel my body is cloaked in strength, solidarity and connectedness. And it reminds me to breathe deeply and to stand tall" (Carolyna Hart-Meade in conversation with Rebekah Harman. Interview, April I, 2019).

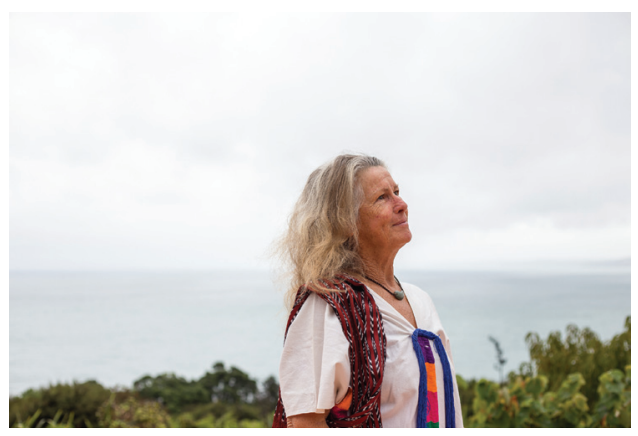

Figure 9. Carolyna Hart-Meade wearing her huipil, worn with a rebozo. These items "remind me to breathe deeply and to stand tall". Photograph: Holly Russell, 2019.

\section{DISCUSSION}

As the study findings show, those interviewed all found strong memories, a sense of place and positive emotions embedded in the garment(s) they had chosen to share. Additionally, all spoke about the aesthetics of the garments and taking care about the types of fibres they are made from (see summary of insights in Figure $1 \mathrm{I}$ ). While three participants mentioned memories when wearing their items, two spoke of the garment evoking a particular positive memory of the past. All spoke of a sense of place how the garment connected them to a particular place (purchasing a scarf at Camden Market in London, or being gifted a huipil and rebozo from México while setting up a shop in Hamilton). All of the participants associated particular positive emotions with wearing the garment (such as excitement, tranquillity, positivity, security and warmth). The aesthetic values of the garment were referred to by all the respondents, with

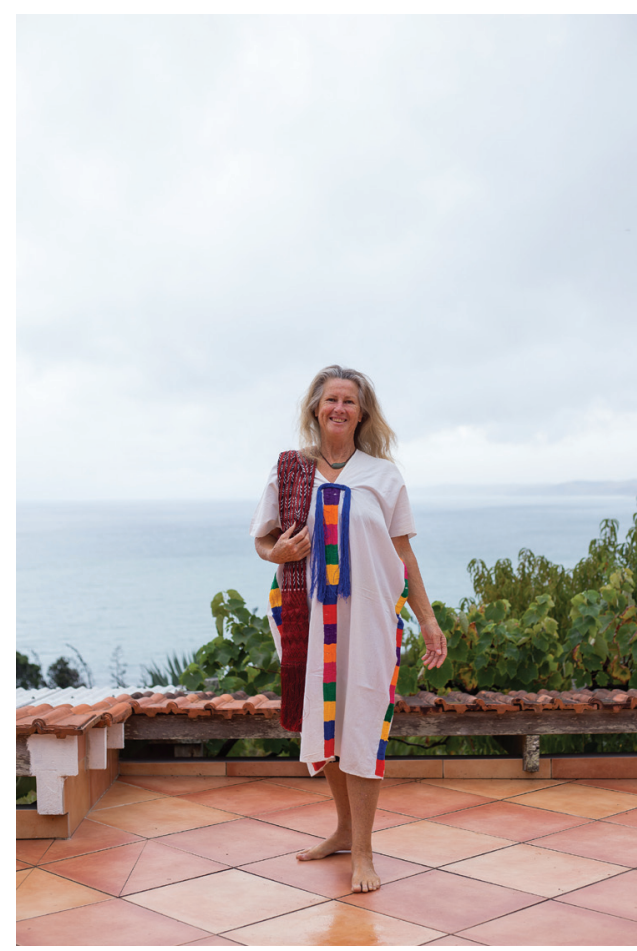

Figure 10. Carolyna Hart-Meade wearing her huipil, worn with a rebozo. Photograph: Holly Russell, 2019.

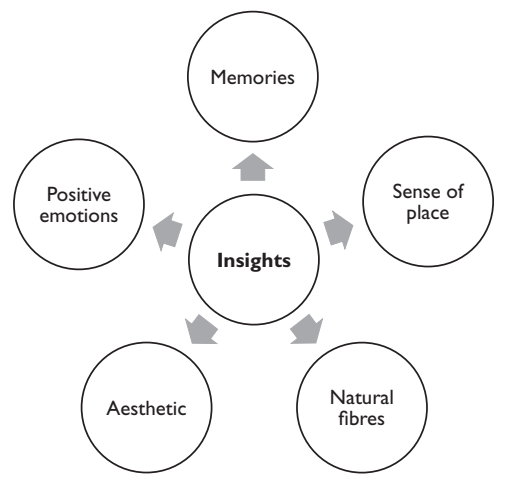

Figure I I. Five key insights into wearers' most loved clothing items according to the five case studies analysed here. 
different people preferring different qualities. All of the participants mentioned natural fibres as being important to them, either because of their feel, connecting these particular fibres to ideas of ethical fashion, or because of the supposed longevity of the garment. The shortest period of time an item had been owned was approximately ten years, and the longest approximately 45 years.

While the study reported here is very small, its findings resemble a much larger study on product attachment. In a study involving 200 people by Schifferstein et al. (2004) examining product attachment, the authors came up with seven key factors that encouraged people to increase their attachment to a particular item (see Figure 12). As paraphrased by Humphries-Smith (2008), these were: "the memories of persons, events and places; the extent to which the product supports the person's identity; the product's utility; the life vision it symbolizes; the enjoyment it activates; its market value and its reliability." The particular similarities with the present study are the memories associated with a person and the significance of places and events. Those interviewed in this research connected their personal values or identity with sustainable fashion, and in all five cases the material the item was made from reflected an important sustainable or ethical choice. Enjoyment was highlighted in a range of positive emotions that were expressed. The reliability of an item was noted as important by four of the five participants.

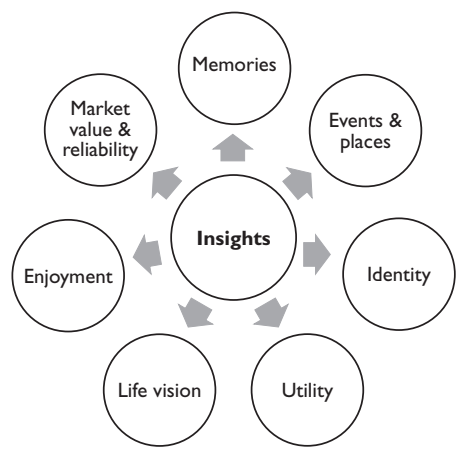

Figure 12. Seven key factors that encourage people to increase their attachment to an item of clothing, as visualised by Rebekah Harman. Based on Humphries-Smith, 2008.

Both Cooper (2005) and Desmet \& Hekkert (2007) discuss the importance of increasing the lifespan of a product through increasing attachment to it. According to Schifferstein et al. (2004), while attachment to an item decreases after one year, anything that has been kept for over 20 years has the highest levels of attachment. These figures fit with the research reported here, as each item in the study had been owned for between ten and 45 years. There are implications for the fashion industry here - it will be important to consider carefully the fibres used in making garments, as they need to be able to last more than a year to allow an individual to become attached to the item. Clearly, these are important points to grasp when considering extending the use phase of a garment.

In their study, Schifferstein et al. concluded that designers need to explore ways for people to become attached to a product through linking "the product and people, places or events (memories)," and that the product should be designed in such a way as to create enjoyment (Schifferstein et al., 2004, p. 330). Their findings reveal the sociocentric dimension that is part of sustainable design, through re-using materials and increasing the lifespan of a product. Additionally, they reflect recommendations by Fletcher, that a better understanding of the way people use garments and their real experiences of wearing them can help us devise new strategies to slow the pace of fashion consumption, in turn lessening waste from the fashion industry.

As the fashion industry continues to grapple with the disruptive effects of creating a more sustainable and ethical industry, fashion designers have an opportunity to investigate the theory of consumer behaviour and product attachment. Continuing this type of research will enhance our understanding of the strategies needed to encourage consumers to make an emotional attachment to a garment and therefore wear it for longer. 


\section{CONCLUSION}

The findings of this research project align with previous literature on the subject (Schifferstein et al., 2004; Cooper, 2005; Desmet \& Hekkert, 2007). All participants could identify specific significant memories and a sense of place associated with the garments they chose to speak about. Designers need to consider how they might design garments that facilitate their becoming a holder of memories. The participants all identified natural fibres as being an important sustainability consideration when purchasing or treasuring a garment. When designing garments, the choice of textiles is an important consideration in order to create pieces that will last long enough to become layered with the wearer's memories, in the way the study participants spoke about. Garments need to withstand more than one year of constant wearing. The small sample of case studies considered here offers a strategy for further research to allow us to better understand the ethnography of clothing in order to ensure a sustainable future for the fashion industry. The more that is understood about ways of ensuring the longevity of a garment's 'used' life, the closer we will be to creating more sustainable consumption of fashion and disrupting current wasteful models of fashion consumption.

Rebekah Harman is a senior academic staff member in the School of Media Arts Te Kura Pāpāho, Wintec, Hamilton, New Zealand, working with undergraduate and postgraduate students. Rebekah's background is in fashion and textile design; she was involved in research and development projects in the wool industry before working full-time as a fashion design tutor and lecturer. Her Master's thesis examined ways of lowering energy and chemical use in the colouration process of wool yarns. Her continuing passion is examining ways to reduce the environmental footprint of the fashion industry.

Contact: rebekah.harman@wintec.ac.nz 


\section{REFERENCES}

Amed, I., Berg, A., Balchandani, A., Hedrich, S., Rölkens, F., Young, R., \& Poojara, S. (2020). The state of fashion 2020. The Business of Fashion, and McKinsey \& Company. https://www.businessoffashion.com/reports/news-analysis/the-state-of-fashion-2020-bofmckinsey-report-release-download

Casey, B. (2021, May 12). A global avalanche of used clothing is coming. NZ needs to do more to save it from landfill. Spinoff. https:// thespinoff.co.nz/society/ I 2-05-202 I/theres-a-global-avalanche-of-used-clothing-and-nz-needs-to-do-more-to-save-it-fromlandfill/

Chrysochou, P. (2017). Consumer behavior research methods. In G. Emilien, R. Weitkunat, \& F. Lüdicke (Eds.), Consumer perception of product risks and benefits (pp. 409-428). Springer International.

Cooper,T. (2005). Slower consumption: Reflections on product life spans and the "throwaway society." Journal of Industrial Ecology, $9(1-2), 5 \mid-67$.

Desmet, P., \& Hekkert, P. (2007). Framework of product experience. International Journal of Design, I ( ), 57-66.

Eder-Hansen, J., Chalmer, C., Tärnegerg, S., Tochtermann, T., Seara, J., Boger, S., Theelen, G., Schwarz, S., Kristensen, L., \& Jäger, K. (20 I7). Pulse of the fashion industry 20 1 7.The Boston Consulting Group and Global Fashion Agenda. https://staticl.squarespace.com/ static/58 I 0348d59cc68e529b7d9ba/t/596454f7 I 5d5db3506 l ea63e/ I 499747644232/Pulse-of-the-Fashion-Industry_20 I 7. pdf

Fashion Revolution. (n.d.). About. https://www.fashionrevolution.org/about/

Fashion Revolution. (2017). Love story: A fashion revolution challenge. https://fashionrevolution.org/wp-content/uploads/2016/03/ FashRev_LoveStory_2017.pdf

Fletcher, K. (20 I I). Post-growth fashion and the craft of users. In A. Gwilt \& T. Rissanen (Eds.), Shaping sustainable fashion: Changing the way we make and use clothes (pp. 165-176). Routledge.

Humphries-Smith, T. (2008). Sustainable design and the design curriculum. Journal of Design Research, 7(3), I-I5. https://doi. org//0.1504/JDR.2008.024194

Klein, N. (1999). No logo:Taking aim at the brand bullies. Knopf Canada.

Ko, K. K., Ward, S., \& Ramirez, M. (20I5). A framework for understanding the role of product attachment in enabling the sustainable consumption of household furniture. In T. Cooper, N. Braithwaite, M. Moreno, \& G. Salvia (Eds.), PLATE: Product Lifetimes and the Environment conference, Nottingham, United Kingdom, I 7-19 June 2015 (pp. 175- I83). Nottingham Trent University: CADBE.

Koperniak, S. (2015, October 29). MIT climate CoLab, in collaboration with Nike, launches new materials competition. MIT News. http://news.mit.edu/20 I 5/nike-mit-climate-colab-apparel-materials-sustainability-contest- 1029

Kvale, S. (1996). InterViews: An introduction to qualitative research interviewing. Sage Publications.

Lehmann, M., Arici, G., Boger, S., Martinez-Pardo, C., Krueger, F., Schneider, M., Carrière-Pradal, B., \& Schou, D. (2019). Pulse of the fashion industry: 2019 update. Global Fashion Agenda, Boston Consulting Group, and Sustainable Apparel Coalition. http:// media-publications.bcg.com/france/Pulse-of-the-Fashion-Industry2019.pdf

Packard,V. (1960) The waste makers. David McKay.

Safi, M., \& Rushe, D. (20I 8, April 24). Rana Plaza, five years on: Safety of workers hangs in balance in Bangladesh. The Guardian. https:// www.theguardian.com/global-development/20 / 8/apr/24/bangladeshi-police-target-garment-workers-union-rana-plaza-fiveyears-on

Scheifferstein, H., Mugge, R., \& Hekkert, P. (2004). Designing consumer-product attachment. In D. McDonagh, P. Hekkert, J.Van Erp \& D. Gyi (Eds.), Design and emotion: The experience of everyday things (pp. 317-321). Taylor \& Francis.

Thomas, D. (2019, August 29). The high price of fast fashion. The Wall Street Journal. https://www.wsj.com/articles/the-high-priceof-fast-fashion- I I 567096637\#: :text=As\%20a\%20whole\%2C\%20the\%20world's,by\%20the\%20British\%20charity\%20 Barnado's

United Nations. (2015). Population 2030: Demographic challenges and opportunities for sustainable development planning. Department of Economic and Social Affairs, Population Division. https:/www.un.org/en/development/desa/population/publications/pdf/ trends/Population2030.pdf

Zhang, B., Zhang, Y., \& Zhou, P. (2021). Consumer attitude towards sustainability of fast fashion products in the UK. Sustainability, 1 3(4), Article 1646. https://doi.org/ | 0.3390/su I 304 I 646 